\title{
Batik Artisans' Judgment of Batik Wax Quality and Its Criteria: An Application of the Many-Facets Rasch Model
}

\author{
Komarudin Kudiya, Bambang Sumintono, Setiawan Sabana \\ and Agus Sachari
}

\begin{abstract}
Batik is a traditional dyeing technique that uses hot melted wax on natural fabric. The wax is applied to the fabric, left to dry, then the fabric is dyed using cold water dyes. Wax quality is central to the batik process and, in the Indonesia region, there are ten standard criteria used to measure the batik wax quality. This study used five batik wax samples tested by twenty batik artisans according to those standard evaluation criteria, and the ensuing data were analyzed using the many-facets Rasch Model. The study found that one criterion, the cost of wax making is regarded as the most difficult item for the batik artisans to endorse. Two criteria for judging batik wax quality, namely 'easy to set' and 'not sticky' are two items that elicited unexpected responses from raters.
\end{abstract}

Keywords Batik wax - Batik artisan assessment $\cdot$ Batik wax testing Multi-rater assessment • Many-facets Rasch Model

\section{Introduction}

Indonesian batik has a key place in world of fabric fashion. It originated in Java and was listed by UNESCO in 2009 on the Representative Lists of the Intangible Cultural Heritage of Humanity (UNESCO, 2009). The use of batik by Indonesians can be seen in different garments worn by women and men, such as a head cloth (iket kepala), shawl (selendang), two kinds of wrapped skirts (kain panjang and sarong), and drawstring pants (celana) (Boehlke, n.d.). Indonesians use batik apparel for casual wear and on formal occasions showing that batik forms part of their cultural life.

Batik is a process of making motifs or ornaments on certain materials, mostly cotton fabric, by using hot wax as the dye repellent (McCabe, 2004). The batik wax

K. Kudiya - S. Sabana $\cdot$ A. Sachari

Faculty of Fine Arts and Design, Institut Teknologi Bandung, Bandung, Indonesia 
ERROR: undefined

OFFENDING COMMAND: ‘

STACK: 